\title{
Community-campus collaborations for food justice: Strategy, successes and challenges at a teaching-focused college
}

\section{FoodDignity}

\author{
Alicia Swords, ${ }^{\text {* }}$ Amy Frith, ${ }^{\mathrm{b}}$ and Julia Lapp c \\ Ithaca College
}

Submitted March 7, 2018 / Revised June 6 and July 10, 2018 / Accepted July 11, 2018 /

Published online July 18, 2018

Citation: Swords, A., Frith, A., \& Lapp, J. (2018). Community-campus collaborations for food justice: Strategy, successes and challenges at a teaching-focused college. Journal of A griculture, F ood Systems, and Community D evelopment, 8(Suppl. 1), 261-277. https:/ / doi.org/ 10.5304/ jafscd.2018.08A.009

Copyright ( 2018 by the Authors. Published by the Lyson Center for Civic Agriculture and Food Systems. Open access under CC BY license.

\author{
Abstract \\ Community-campus engagement in higher edu- \\ cation provides educational experiences for \\ students to grapple with complex, real-world \\ problems, including the lack of equitable access to \\ healthy food for all. In this reflective essay, three \\ faculty members of a teaching-focused college \\ report and reflect on the benefits and challenges of \\ a* Corresponding author: Alicia Swords, $\mathrm{PhD}$, Associate \\ Professor, Sociology; D epartment of Sociology; 072 Peggy \\ Ryan Williams Center; Ithaca College; Ithaca, NY 14850 USA; \\ +1-607-274-1209; aswords@ithaca.edu \\ b Amy Frith, PhD , Associate Professor, D epartment of Health \\ Promotion and Physical Education; G 47 Hill Center; Ithaca \\ College; Ithaca, NY 14850 USA; +1-607-274-5135; \\ afrith@ithaca.edu \\ c Julia Lapp, PhD , RD , Associate Professor, Nutrition; \\ Department of Health Promotion and Physical Education; \\ G 45 Hill Center; Ithaca College; Ithaca, NY 14850 USA; \\ +1-607-274-3943; jlapp@ithaca.edu
}

community-campus engagement through a food justice education action research project called Food Dignity, funded by the U.S. D epartment of Agriculture. Achievements included developing a curricular approach, preparing students for community partnerships and community-based research, strengthening institutional commitment to community-campus engagement, and establishing community and institutional networks. O utcomes include that student participants revised

\section{Funding Disclosure}

Food Dignity (http:/ / www.fooddignity.org) was funded by USD A National Institute of Food and Agriculture's Agriculture and Food Research Initiative Competitive G rant no. 2011-68004-30074.

\section{Contributors and Supporting Agencies}

Blue Mountain Associates; Feeding Laramie Valley; Whole Community Project; East New York Farms!; Dig D eep Farms; University of Wyoming; and the U.S. D epartment of Agriculture National Institute of Food and Agriculture. 
their values and attitudes about the food system and their ability to change it. We discuss challenges, including academic supremacy and unequal power relations, and offer recommendations for future community-campus food justice initiatives.

\section{Keywords}

Community-Campus Engagement; Community Food Systems; Food Justice; Food System Education; Service-Learning; Community-Student Engagement; Food Dignity

\section{Introduction}

This paper describes, from the perspective of three faculty $^{1}$ at a teaching-focused ${ }^{2}$ college, how a community-campus project with educational and service-learning components affected curriculum development, faculty and student engagement with community partners, and structural change at our institution. Food D ignity funds for our college were allocated to compensate student interns working with community partners and, in some cases, the community partners themselves. ${ }^{3} \mathrm{We}$ begin by reviewing relevant literatures on community-campus engagement, especially those focused on food justice. We describe our institutional context and initial goals for the project of developing new opportunities for communitycampus engagement with the local food system. We then outline our curricular initiatives, highlighting our developmental approach to communitycampus engagement. After evaluating the impacts of our initiatives based on data from student surveys and student reflections, we discuss the successes and challenges of this project and reflect on implications for addressing underlying causes of food injustice.

\footnotetext{
${ }^{1}$ In this paper, the personal plural "we" or "our" is used to refer to the three Ithaca College faculty (Alicia Swords, Amy Frith, and Julia Lapp), except when otherwise specified. 2 The terms teaching ollege (Cofer, 2017), teaching-focused ollege (Nemtchinova, 2013) or teaching-intensive institution (Phelps, 2013) have been used to refer to a type of institution of higher education where faculty are "expected to teach, on average, four courses a semester; advise students; participate in service work both on the campus and in [their] discipline; and pursue scholarship" (Cofer, 2017). This type of institution typically
}

\section{Community-Campus Engagement and Service-Learning}

The field of civic engagement aims for learning and mutual benefit via intentional relationships among students, academic institutions, civic organizations and community members (Furco, 2007; Gelmon, Holland, Seifer, Shinnamon, \& Connors, 1998; Hullender, Hinck, Wood-Nartker, Burton, \& Bowlby, 2015; Jacoby, 2009; Stoecker \& Tyron, 2009). Civic engagement in higher education has been operationalized through volunteering, community service, and service-learning. Servicelearning is a "teaching and learning strategy that integrates meaningful community service with instruction and reflection to enrich the learning experience, teach civic responsibility, and strengthen communities" (Niewolny et al., 2012, p. 31). While historically service-learning practices focus on student learning (Kiely, 2005), some use critical theory and pedagogy (Freire, 1970) to ask who is served and who decides about these initiatives (Bortolin, 2011; Stoecker \& Tryon, 2009). Increasingly, scholars and practitioners recommend that service-learning projects adopt explicit social justice goals, genuine relationships, commitment to redistribute power, reciprocity, activism, and other goals of broader social and institutional change (Levkoe et al., 2016; Marullo \& Edwards, 2000; Mitchell, 2008; Swords \& Kiely, 2010).

We began this project with these commitments, aligning our practice with the move from a transactional (Enos \& Morton, 2003), charity-based approach (Ward \& Wolf-Wendel 2000) to a transformative learning model of service-learning (Clayton, Bringle, Senor, Huq, \& Morrison 2010; Kiely 2005), including reciprocity and commitment to changing power relationships. In this model, all participants grow, change, and explore emergent

has fewer than 10,000 students, small class sizes, a low student/ instructor ratio, and expects close mentoring of students by faculty (see Nemtchinova, 2013).

3 We were not compensated financially by Food Dignity project funds for our participation in this project or for our summer work, although we earned our usual nine-month salaries from Ithaca College. For further information on Food Dignity funding see Porter and Wechsler (2018). For more information on the project and community partners see Porter (2018). Both papers are in this issue. 
possibilities; engagement is open-ended and longterm; and there is a commitment to revise goals and move beyond status quo practices (Clayton et al., 2010). We draw on Kiely's (2007) four-part framework for reflective practice in servicelearning by attending to pedagogy and curriculum, research, community development, and institutional change.

\section{Food Justice and Community-Campus Engagement}

The Food Dignity project that our service-learning collaboration was part of relates to the realm of food justice. Food justice is a concept promoted by an emerging food movement in North America, which references the food sovereignty movement in the global South. It brings together individuals and organizations that advocate for food security and sustainable agriculture (Levkoe, 2006). The movement critiques the industrial food system, advocating changes related to equity and trauma, exchange arrangements, land, and labor (Cadieux \& Slocum, 2015). Food justice advocates vary widely in their ideologies, approaches, and disciplines, and use a variety of concepts including sustainable food systems, civic agriculture, and community food systems. While distinct, they all share basic concerns with equity, food access, sustainability, and health (see Alkon \& Norgaard, 2009; Broad, 2016; Gottlieb \& Joshi, 2010; Holt-G iménez, 2010; Winne, 2008).

With the spread of food justice initiatives, institutions of higher education are increasingly partnering with food justice organizations for civic engagement teaching and research (Allen, 2008; Galt, Parr, Van Soelen Kim, Beckett, Lickter, \& Ballard, 2013; G ray, Johnson, Latham, Tang, \& Thomas, 2012; Holt-G imenez, 2010; Levkoe et al., 2016; Meek \& Tarlau, 2015; Sbicca, 2015). While the food justice movement focuses on changing policies and systems surrounding food, environment and health, in many cases, universities offer gardens, technical assistance, produce local foods, or otherwise address short-term community needs

\footnotetext{
4 We learned about a number of simultaneously occurring
community-campus food justice initiatives as our project was

4 We learned about a number of simultaneously occurring
community-campus food justice initiatives as our project was in process.
}

Volume 8, Supplement 1 / July 2018
Some also include goals of changing university practices (Burley et al., 2016; Clark, Byker, Niewolny, \& Helms, 2013; Niewolny, SchroederMoreno, Mason, McWhirt, \& Clark, 2017). These initiatives have different impacts on community members, organizations and students. As civic engagement increasingly examines power and justice, critical studies on community-campus food justice initiatives call for campuses to address racism and classism, both in the food system and as they are reproduced in partnerships (Alkon \& Norgard, 2009; Meek \& Tarlau 2015; Sbicca 2012, 2015).

A number of case studies describe best practices in community-campus partnerships for food justice to mitigate against racial and class inequities. ${ }^{4} \mathrm{G}$ ray et al. (2012) advocate for orientation programs for students to develop sensitivity to issues of power and respect before interacting with community members. Best practices include reciprocity, building trust, connecting to personal experiences, finding common strategies (Levkoe et al., 2016), reflection, active listening, and openness to addressing whiteness, privilege, and racial inequality (Sbicca, 2015). In some cases, students and community partners collaboratively establish long-term project goals and outcomes, which can include changing college and university curriculum (Niewolny et al., 2017).

At the same time, some case studies reveal the challenges of community-university food justice projects. G ray et al. (2012) highlight the challenges of balancing the diverse needs and goals of funders, partners, and community members in a garden project at Santa Clara University. Rosing (2012) cautions academics to avoid extraction from local communities (via student training and data) and to avoid replicating nonprofit initiatives that align with neoliberal policies that disavow government responsibility for addressing social inequity. Bortolin's (2011) analysis of academic articles on service-learning found that even as academics espouse service to the community, they exploit the 
community for their own ends. "Community" was treated as a means by which the university enhances its academic work; as a recipient of university influence; as a place the university makes better; or as a factor in the financial influence of the university. We aimed to avoid these pitfalls. Increasingly, scholars emphasize that academics must acknowledge and address unequal power relationships (Bortolin, 2011; Porter \& Wechsler, 2018; Stoecker \& Tryon, 2009; Swords \& Kiely, 2010).

The objective of this reflective essay is to contribute a case study of community-campus engagement to the empirical literature on the practice of teaching about food justice in higher education, in hopes of contributing toward broader social justice and sustainability.

\section{Institutional Context: Ithaca College}

A core aspect of the five-year Food Dignity project was for educational institutions to interface with community organizations to address local food justice issues, such as support for local food production, access to healthy, nutritious food, and entrepreneurship to improve food access for lowincome populations. O ur role as Ithaca College professors in Food Dignity centered on student learning through community engagement. ${ }^{5}$

As Food D ignity launched in 2011, Ithaca College was just beginning to incorporate educational programming on community engagement at an institutional level (Furco, 2002). Prior to this, community-campus engagement had occurred without formal institutional support. The college had not covered administrative costs, compensated community partners, or offered faculty release time or financial compensation. Still today, investments of faculty time in community engagement have not been rewarded consistently through tenure or promotion. Without an institutional commitment, initiatives have been poorly coordinated. D espite

\footnotetext{
5 Ithaca College, a comprehensive teaching institution with approximately 6,200 students located in Ithaca, New York, has a long history of engagement with community organizations. Faculty, staff, and some students are community residents; we are involved as board members, volunteers, or participants with local organizations. Significant "town-gown" links (i.e.,
}

these institutional obstacles, we were drawn to Food Dignity because it offered opportunities for us, our students, and our communities to challenge systemic inequalities through engagement with the food system.

\section{Developing Project Goals: Thinking Beyond Internships}

As the principal investigator, Christine M. Porter, was developing the Food Dignity proposal in 2010, she proposed that we join the project by involving our sociology and nutrition students in community organizations in food dignity-related internships. This proposal was echoed by community organizations in Ithaca and Tompkins County, New York, including Cornell Cooperative Extension of Tompkins County, the Whole Community Project, and Gardens4Humanity. These groups were working on issues such as community gardens, food access, local food production, and food justice education, and were interested in working with students to accomplish their goals. We anticipated a mutually beneficial community-student engagement opportunity to promote changes in the food system.

Initial discussions with project leaders and community partners conceptualized communitycampus engagement primarily as internships lasting at least a semester. Based on previous work, we knew that students needed foundational training and intensive mentoring to manage the responsibilities of meaningful internship experiences and to not burden agency supervisors or organizations. We also recognized that even students who might not become interns could benefit from exposure to food dignity issues and organizations. While we were committed to intensive engagement, we also believed it could be possible and was necessary to offer introductory and intermediate-level opportunities that required less preparation, community resources, and mentoring. To this end, we developed a model of community-campus engagement

between higher education institutions and their surrounding communities) are also forged as students work with community organizations as interns, volunteers, or through course assignments for academic credit. The histories of these types of community-campus ties are not simple or all positive (Stoecker \& Tryon, 2009). 
that would meet the variable needs of community partners and students.

We articulated two goals. First, we aimed to offer Ithaca College students a meaningful sequence of learning opportunities to get involved with local food justice efforts by developing a pedagogical process to build student involvement gradually. Second, we wanted to develop a program to prepare students for working successfully in food justice-related community engagement projects in diverse communities. This required building meaningful relationships that could allow students to contribute toward community organizations' goals.

\section{Development of the Cumicular Approach}

We conceptualized a curricular approach that we called the "O nion of Community Student Engagement" (see Figure 1). In our 2012 annual report (unpublished) we wrote, "This is our vision for the pedagogical process of bringing students into engagement with food dignity issues and community organizations. We envision it happening over several years. O ur work in each layer aims to be always in communication with the larger Food Dignity network and the collaborating community organizations in our county." We envisioned this as a developmental curriculum design because it introduced increasingly complex levels of learning about community food issues.

In this model, the outer layer represents the opportunity to reach a larger number of students across campus by building awareness through structured community-student interactions with food justice topics through campus events and as lessons and activities in sophomore-level classes. Moving toward the center of the onion, a smaller number of interested students could participate in semester-long projects in upper-level courses,

Figure 1. The Onion of Community-Student Engagement for Food Dignity

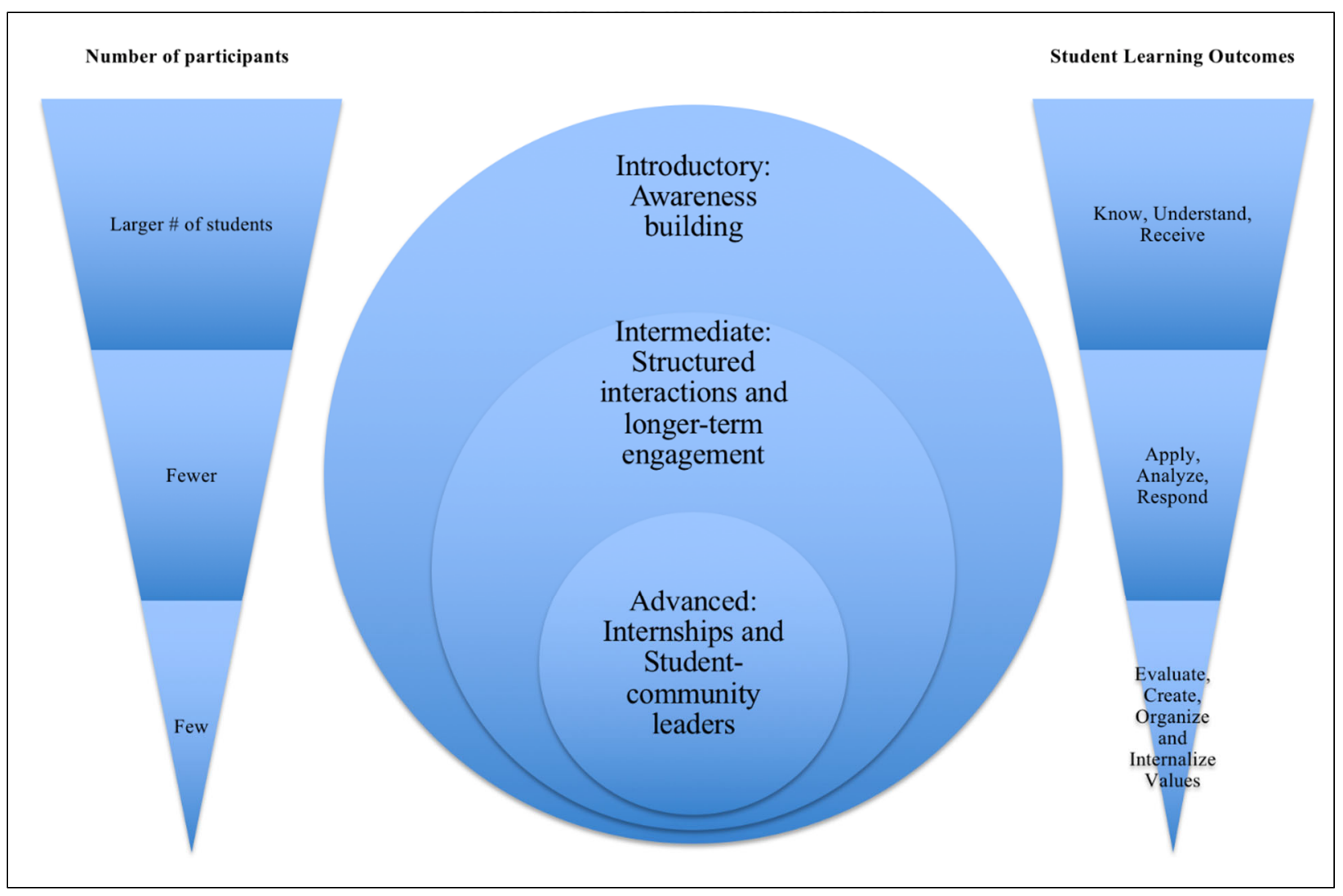

Sources: Anderson \& Krathwohl, 2001; Bloom, 1956; Howe, Coleman, Hamshaw, \& Westdijk, 2014. 
strengthening the knowledge and skill base needed for students to possibly later become interns with community organizations (center of the onion). Internship positions were intended for only a few students who wished and were prepared to spend greater amounts of time, in their junior and senior years, mentored by community partners and later to become leaders/ mentors for incoming interns.

O ur approach prioritizes the goals of fostering students' increased awareness and exploration of food injustice and the systems that perpetuate it. Attainment was conceptualized as a process, and we made both the goal and the activities to support it explicit to the students from the beginning. As we developed the onion model, we learned of the three-fold approach for service-learning by Howe, Coleman, Hamshaw, and Westdijk (2014), which reviewed moral, psychosocial, and cognitive development to advocate for structuring student experiences from exposure through capacitybuilding to full responsibility. The instructor "scaffolds," or provides "support as the student climbs toward the next level of understanding or capacity, and to gradually remove (or shift) that support as the student becomes more skilled and confident (as the metaphoric building stands more securely on its own)" (Howe et al., 2014, p. 46). Howe et al.'s developmental theories of learning informed us and confirmed the underpinnings of our approach.

We gathered input from community partners to design food dignity units with shared community engagement opportunities for our courses. Though not all learning activities were coordinated, we developed a framework of common student learning outcomes for our courses. We experimented with learning outcomes at first, and as we observed student responses, added them explicitly to our curricular approach. As students progressed, outcomes required more advanced levels of learning, following Bloom's taxonomy for levels of knowledge (1956), from knowledge, comprehension, application, analysis, and synthesis, to evaluation. O utcomes also corresponded to Anderson and Krathwohl's (2001) affective learning taxonomy, whereby learners move from receiving and responding to phenomena to valuing, organizing, and internalizing values. We intended for students to gain increasing knowledge, practice skills, and internalize values related to food dignity as they moved from introductory courses to senior capstone courses or internships. Similar to Howe et al. (2014), students gained increasing responsibility for collaborating with community members in identifying project goals and for implementation and as they deepened their engagement.

Introductory L evel: A wareness-building and 0 utoomes An estimated 1,000 students were involved in introductory awareness-building activities during the five years of the project. We drew on input from community leaders and agreed on common learning outcomes for our introductory nutrition and sociology courses. These included defining food dignity; describing systemic obstacles to food dignity; comparing food dignity with unjust food systems; and recognizing local initiatives to improve food dignity.

Common learning activities were required for all of our nutrition and sociology students. For example, we organized a public panel discussion of speakers from farms and organizations involved in local food production, distribution, and education. Panelists discussed the contemporary food system and suggestions for becoming involved in changing it. We assigned and guided reflection on common readings to prepare students for discussions before, during and after the panel.

To increase the level of engagement for introductory students, we assigned structured community-based activities. For example, students in our 200-level classes participated in the local Food Justice Summit in 2012 and 2013, joined a community walk, and attended a public talk by a food justice leader.

At the awareness-building level, we assessed student learning outcomes and shifts in beliefs using surveys, course evaluations, and reflective writing assignments. Pre- and post-surveys administered to students who attended the Food Dignity panel tracked shifts in knowledge, beliefs, and values related to food systems, based on the panel discussion and assigned readings. Survey items used Likert scales ranging from 1 (no importance or commitment) to 5 (extremely important or committed). Thirty-six percent of students 
increased their rating on the importance scale from pre to post-survey, indicating that local foods were more important to them after the panel, while the remainder of the students' ratings remained the same. Thirty percent of students increased their rating on the importance scale for consuming organic foods, while the remainder remained the same. Similarly, from pre- to post-survey, commitment increased among $63 \%$ of students regarding buying local foods; $46 \%$ to buy organic foods; and $46 \%$ to buy more humanely raised meats and dairy foods. On questions regarding awareness of food justice values, measured by agreement on a 1-to- 5 Likert scale, about $25 \%$ of students increased their agreement that improving people's access to food requires addressing economic inequality. A similar percentage increased their agreement that it is difficult for many working families to have access to healthy food. From these surveys, we found that over one-third of the students reported improved awareness and systems thinking related to food justice due to the panel and assigned readings. Students reported bigger changes in value and commitment to food consumption behaviors, such as buying local and organic foods, than in awareness of larger social issues. This difference was somewhat expected, as understanding systemic inequities requires higher-level analysis and emotional engagement.

In the sociology course taught by Swords, called Gender, Environment, and Global Change, students studied the causes of hunger in the U.S. and the world. In their postpanel survey, student explanations for hunger included "structural and institutional inequalities" and "the way our political and social systems are set up that make it so food isn't distributed properly." The emphasis in the course on systemic inequalities helped reinforce the awarenessraising objectives of the panel.

Intermediatelevel: E ngagement

A smaller number of mid- and upper-level students engaged in longer-term activities (one to two semesters) that included cultural competency trainings, student projects with the Food Bank of the Southern Tier (FBST), Cooperative Extension, and community meal programs. Over the course of the Food Dignity grant, approximately 200 stu- dents were involved at this level. For midlevel nutrition students, these activities included a class project of providing nutrition education to childcare workers for state-required trainings, leading cooking classes, and offering grocery store tours for community members. Sociology and nutrition students piloted hunger education workshops for FBST in high school and elementary classrooms. Upper-level nutrition students worked Cornell Cooperative Extension of Tompkins County to offer cooking and nutrition education classes to income-qualified community members through Cooking Matters, a program of the national nonprofit Share O ur Strength. Students from upperlevel nutrition courses also worked at the Food Justice Summit to distribute information and answer questions from the public regarding food justice issues, initiatives, and organizations.

At this level, from 2010 to 2012, we helped to develop a pilot cultural competency training for students who would be working with community partners. In this training, community members were invited to collaborate with faculty in designing and implementing the training, and community members were paid as educators. According to Y arborough and Wade (2001), student training is essential for service-learning success, but providing it can burden community organizations. We made every attempt to adequately prepare students before they began work with our partnering community organizations. $\mathrm{O}$ ur training aimed to instill respect for community members and to address historical power imbalances between campus and communities, as discussed below.

At the intermediate level, learning outcomes were that students could describe connections among sustainability, food insecurity, and food dignity; describe changes in their own views and values as a result of a structured interaction focused on food dignity with an organization or community member; describe successes and challenges of initiatives for food dignity; and characterize the impact of historical power structures including racism, poverty, and sexism on food dignity.

We collected reflections from students who participated in the cultural competency training and coded them for themes related to food dignity. Students demonstrated an initial understanding that 
poverty, racism, and sexism exacerbate food insecurity. They also described connections among sustainability, food insecurity, and food dignity. In Spring 2015, one student indicated, "sustainability is key and dignity is a key to sustainability.... F ood insecurity is not just about getting people food and shelter, but restoring them to [be] functioning members of society that have a strong sense of dignity. Short-term solutions will only delay the problems of food inseaurity and the country needs people to have a lasting sense of dignity to aid them in their lives." This student's doubt about the viability of shortterm solutions evidenced a developing awareness of the systemic nature of injustices.

After intermediate-level engagement, students demonstrated the ability to explain dimensions of food dignity. "F ood dignity is taking control of the food we produce"; "F ood dignity is being proud of what we are feeding our children and of how we are treating the earth." They also described actions or strategies that could contribute to increasing it. "Be involved with production and distribution"; "A lso realization that U S has a big problem"; "W e could increase dignity if we had a part in the food we produce and feed our families and ourselves. The way we produœ and distribute food in the U S is seriously lacking in dignity." Student evaluations described their potential to contribute through engagement in the food system.

After participating in the cultural competency training, students showed the ability to recognize and describe the divide between academics and community members. "I [also] learned that they [ommunity members] really feel a separation between students and community members that I have been unable to see because of how sheltered I am on [compus]." Some students were able to notice and describe power relationships between academics and community members. "I think it is difficult for students to go into the community to 'educate' or 'teach' and understand that this is a learning ex perience for everyone- not just those we are work ing with."

However, students went beyond recognizing obstacles to express the desire to break down barriers and shift power relationships.

I want to become more aware of the way I look, talk, and interact and how it influenoes others' perceptions of me and ex periences with me. I have been noticing people around me speaking in ways that are very disrespectful to diversity and I want to find ways to increase the conversation of cultural competency.

[T his ex perience] has made me so ex cited to make connections and deeply learn from [oommunity members].

In describing their desire to learn from community members, students express an interest in contributing to new power relationships.

A dvanoed L evel: Internships and Student

Community L eaders

The innermost layer of the onion model represents a select number of students who were able to develop the knowledge, skills, and relationships to become interns, independent researchers, and student community leaders in relation to Food Dignity. The original goals of the Food Dignity grant mentioned internships as the only mode of community-campus involvement at our college. The grant required that we coordinate with organizations in Tompkins County that could receive a small stipend to mentor up to 10 paid student interns over the five-year period of the grant. This was to be led by the main community partner in Ithaca, the Whole Community Project, and the Cornell Cooperative Extension of Tompkins County office that housed it. Funding for the student interns and community partners was provided by the USD A grant for Food Dignity. Even with help from a project coordinator based at the extension office to match student learning needs with internship opportunities, we were only able to place two Ithaca College students into paid internships over the five years of the Food Dignity grant. D espite our best efforts, connections among community, campus, and the project faltered.

Limiting factors included student constraints, such as credit hours and semester timing, communication failures, and mismatches with community agency needs for timing and skill sets.

Because of these limitations, we found other avenues to engage students at advanced levels. During the project, eight students conducted research and wrote papers focused on topics related to food dignity. Topics included fair trade and food dignity; Walmart and the food system; 
the school lunch program; community-based initiatives regarding food access; and women farmers in Tompkins County. Nine students who were preparing for Food Dignity internships found other placements, including with the Friendship Donations Network, a food rescue organization in Ithaca, New York, and Cornell Cooperative Extension's Cooking Matters program. Four students co-created with community members a recipe book focusing on healthy foods on a budget. Sixteen students contributed to hunger education curriculum design for clients of the FBST. ${ }^{6}$

Another avenue we created to engage students at advanced levels was to teach, mentor, and create opportunities for students to become leaders in community-based initiatives. Six students were involved in this way. For example, nutrition students who had provided hunger education to school children trained and supervised the next group of Ithaca College students providing hunger education. In another case, a student teaching assistant for a Food Dignity-related sociology course was hired by FBST after graduation. In another case, a student who had participated in intermediate-level Food Dignity activities was hired as a summer research assistant.

O ur attempts to create internship opportunities provided valuable process-based information for future efforts in matching students with suitable community-based internships. In the absence of being able to place interns, we provided 43 students with advanced-level learning and leadership opportunities related to food dignity. These students negotiated directly with community members regarding needs and goals. They were responsible for contributing to local organizations, such as by designing educational materials for specific audiences. At this level, students demonstrated that they had internalized the values of food dignity.

\section{Successes}

In this section, we describe our successes in five areas, building on Kiely's (2007) framework: the development of community-campus engagement curricular approach; student involvement in com- munity-based research; institutional commitment to service-learning; professional development; and the establishment of community and institutional networks.

Community-Student E ngagement

Curricular A pproach

O ur curricular goals were to guide students through a developmental sequence of transformational community-based learning related to food justice. In the process of creating and piloting our curricular approach, we drafted rough student learning outcomes, which we refined as the project continued. For example, when students first had contact with the Food Dignity project at the awareness-building level, they became interested in food as a topic of study but did not understand larger structural power dynamics that maintain food inequalities. With more involvement, students began to notice the complex systems of inequality that underlie issues of food justice and dignity. Students who had opportunities for longerterm engagement with food justice organizations learned to describe and give examples of social inequalities, and to identify social and ecological problems in the existing food system.

Student Involvement in Community-based Research on F ood Justice Another success in our Food Dignity-related work is the development of a collaborative research relationship with the Food Bank of the Southern Tier (FBST), through a participatory action research course in sociology and a community nutrition course, both of which focused on food justice. Although the FBST was not one of the funded partners of the Food Dignity project, we turned to them when connections with other community partners were slow to consolidate.

During the grant, we discussed, with each other and with Food D ignity collaborators, whether a food bank could be a player in a move toward a sustainable, just community food system. We agreed that many food banks are deeply embedded in a charity model by playing a role in

${ }^{6}$ The hunger education curriculum is available at https:/ / www.foodbankst.org/ hunger-ed 
profitably disposing of corporate food surpluses and distracting the public from the realities of hunger by offering band-aid solutions (see Poppendieck, 1999). But the president of the FBST demonstrated an interest in building a partnership, shared our social justice orientation, and showed her commitment to making organizational changes. As our partnership evolved into longer-term research and educational projects, the FBST began to adapt its strategic plan. The president led the board of directors and staff in adopting a strategic vision to "end hunger in the Southern Tier"; to "shorten the line" in addition to "feeding the line"; FBST also increased the organization's budget and commitment to hunger education, advocacy, and began involving pantry users in advocacy efforts. An example of success in this area was our collaboration with the FBST and Cornell Cooperative Extension in developing and piloting the Hunger Scholars program food justice curriculum, which continues to be implemented regionally and nationally in schools, after-school programs, and community youth organizations. Ithaca College student leaders also trained and supervised subsequent Hunger Scholars.

In collaboration with the Food D ignity partner Cooperative Extension of Tompkins County, Lapp and Frith planned a community-student project whereby senior students in Health ScienceNutrition who had moved through our curricular approach developed and offered a series of the Cooking Matters nutrition and cooking classes to community members in Ithaca. This higher level of community-student engagement was driven by community partners' stated needs.

In addition, participation in Food D ignity learning opportunities motivated students to explore their commitment to food justice, which helped create avenues for their employment with food-oriented organizations. Many graduates continued their education in social work and health fields.

Institutional $\mathrm{C}$ ommitment to $\mathrm{C}$ ommunityE ngaged L earning By developing community networks, our participation in Food Dignity helped us expand our vision and expectations for institutional support for community-engaged learning. Increasing our connections with community organizations raised our awareness about the needs of local stakeholders and helped us see the need for institutional support for civic engagement. We learned that "we in academia need to do our share of preparing [students] before asking them to engage with community organizations, because if they go full of themselves and their knowledge and what they have to offer... it's that much more work and a burden on the community organization" (as Swords said while interviewing Christine Porter in September 2012).

This awareness motivated us to take part in the strategic planning for civic engagement at Ithaca College, including the development of the Office of Civic Engagement (OCE) at the college. The OCE was a first step toward coordinating efforts of faculty in engaging with community partners based on values of reciprocity and respect, and it was an effort to demonstrate institutional investment in the community. Swords and Frith participated in college-level committees to define servicelearning, set goals, and develop an institutional strategy for implementing the $\mathrm{OCE}$. In the process of developing the office, Swords and Frith invited community members to provide input toward the values and practices of the office. Community needs, input, and criteria for engagement were heard at an early stage of the office's development and affected its path.

Another success was achieving an institutional commitment to offer cultural competency training. After faculty and administrators observed the impact of our 2010-2011 pilot cultural competency trainings for students and faculty, when the $\mathrm{OCE}$ was created in 2012 cultural competency workshops were among its first activities. OCE maintained the commitment that these workshops would be community-led and kept the standard we had set to financially compensate community educators. Subsequently, hundreds of students have attended these trainings. Expanding and institutionalizing the trainings has exposed many students, faculty, and community members to the impact of larger power struggles and structural barriers on food justice. 
Professional D evelopment and N etworks

We benefited professionally from our involvement in Food Dignity. The project gave us additional opportunities to network and speak on issues related to food justice and community research with colleagues and administrators. O ur participation also opened up opportunities to write and obtain grants for further research with community partners. Although we each had completed sufficient scholarly work to earn tenure, participating in this USD A grant contributed to our profiles as scholars and teachers. The project indirectly provided a degree of authority and status that was converted into currency in our profession.

One of the primary beneficial outcomes of our participation in Food Dignity was that it helped us access, build, and strengthen our professional networks with scholars and community members working on food-related issues. Through Food Dignity, we took part in regular local and national meetings where we learned about campus and community needs and strengths, discussed our visions for food dignity, and built rapport and trust. Through interacting with neighbors and civic leaders, we saw the strengths and needs of specific populations in our community, including youth, older adults, residents of public housing, people targeted by racism and discrimination, people living with disabilities, and rural residents. The relationships we built have created opportunities for new and ongoing partnerships, such as work with students, projects, and grants.

We also strengthened our networks with local academic institutions. We were invited to contribute to the design of Comell University's food systems minor. We participated in cross-campus meetings (e.g., Ithaca College, Cornell, and Tompkins Cortland Community College) to propose institutional and curricular coordination of community-student engagement projects and to avoid overwhelming and oversaturating our community partners. Such ambitious attempts did not result in immediate coordination or curricula, but we came to understand possibilities and constraints and built ongoing connections with colleagues at other local institutions.
Challenges: Power Relations and CommunityC ampus E ngagement

Some challenges of this project were due to the intense time pressure that stakeholders experienced. Students found that community agricultural and food projects were out of sync with the academic calendar. In addition, unequal power relationships between community and campus stakeholders exacerbated the logistical challenges. We found engagement to be fraught with difficulties because it involved relationships that are embedded in institutional and historical power differences (see Bringle \& Hatcher, 2002, p. 97; Buckley, 2016; Eyler \& G iles, 1999). To acknowledge the challenges we faced, we reflect here first on power relationships between communities and institutions of higher education. In this special issue, Porter and Weschler (2018) define "academic supremacy" as "systemically inequitable social relations between university partners (individually and institutionally) and community-based people and organizations, that are pervasive and institutionalized in U.S. society" (p. 75). Academic supremacy can be internalized and enacted by academics in social interactions. In addition to this educational and institutional power, we also derive social power and privilege from our social class and our racial and ethnic identities as white people of European heritage.

In our context, the dominant culture of academic supremacy posed challenges to our efforts even as we attempted to challenge it. One dimension was community partners' prior experiences with other faculty and students in other civic involvement situations. In our planning conversations, community partners frequently described having been treated as "recipients" rather than equal partners in the design and delivery of community-campus engagement. For example, a local nonprofit used the term "parachuters" to critique short-term or drop-in student service projects in the community. A public elementary school teacher described her preference for college service-learning students get to know their students and teachers and what they need, rather than giving a "one-off lesson"; she expressed frustration that she was not often asked by college faculty about how their students should engage with her after- 
school program. We noticed that despite our efforts to be thoughtful, we invoked academic supremacy when we or our students assumed that communication should occur with a certain frequency or mode (such as email rather than phone) to suit academic culture, schedules, or preferences. We engaged in sporadic discussions regarding privilege, equity, and control over education with community partners and with other Food D ignity collaborators. Y et in some cases, the power relations, and expectations about them, seemed to be so entrenched that there was not opportunity over the five years of the project to overcome them. We acknowledge that our institutional power separated us from community members' experiences and that our assumptions about communication led us to be frustrated by missed opportunities for student engagement.

A second power dynamic is among the institutions of higher education in our region. There are four institutions within a 30-mile radius. Their funding and status range from community college to Ivy League institution and correspond with the class positions of students and faculty (see Bowles \& G intis, 2002). For example, at a local football game among rivals, when the public college team makes a good play, the fans of the private college cheer, "It's all right, it's $\mathrm{OK}$, you're gonna work for us someday!" The public college might win at football, implies the cheer, but that does not change their students' prospects for class mobility and status. In cutting fashion, this chant reminds the public college students of their place in the class hierarchy. This class hierarchy inadvertently played out in our project because it was apparent even in our service-learning collaborations that our institutions seem to be perceived differently among community members. Class hierarchy was also reflected in the funding structure of the project overall, since the research institutions' budgets included graduate student research, while ours was focused toward undergraduate learning.

These power imbalances, between institutions and community residents and among institutions themselves, can create significant barriers to productive interactions for successful service-learning. We hoped to begin preparing students by moving through the onion and cultural competency training so that they would view community members as experts, and thereby would begin addressing these inequities in power relations. In addition, we were trying to move students away from the charity model to a strengths-based model in working with communities.

\section{Discussion and Conclusions}

We entered the Food Dignity project with the goal of bringing together community members and students to create mutually beneficial relationships, experiences, and collaborations focused on food justice. We conclude by outlining how our experiences reinforce and contribute to the literatures on the necessity of institutional change and professional development, community-campus relationships, and pedagogy in service-learning. Finally, we suggest lessons for future community-campus food justice initiatives.

Institutional C hange and Professional D evelopment O ur experience shows that faculty-, student- or community-led initiatives are insufficient without institutional support. Institutions can assist community-campus collaboratives by creating communication bridges for dialogue with communities to assess common interests. It is also important that they prepare faculty through professional development. Another institutional support we did not address at Ithaca College is the acknowledgment of faculty contributions for campus-community collaborations in tenure and promotion assessment. Future efforts can draw on the emerging literature on faculty development and institutional change (Holland, 2016; Kiely \& Sexsmith, 2018) to support service-learning and civic engagement. There is still much that institutions can do to move away from academic supremacy (Porter \& Weschler, 2018), from charity models (Ward \& Wolf-Wendel, 2000), and from exercising privilege over community organizations (Bortolin, 2011) to transformative relationships (Clayton et al., 2010).

Community-Campus Relationships

O ur experiences confirm the emphasis in critical service-learning literature on quality communitycampus relationships. In building such relation- 
ships for Food Dignity, we implemented many of the best practices proposed by Sbicca (2015) and Levkoe et al. (2016). These include active listening; addressing whiteness, privilege, and racial inequality; aiming for reciprocity, and building trust. Our work shows that these practices create the possibility for collaborative work and also signal the particular challenges of academic supremacy (Porter \& Weschler, 2018). Without trust, reciprocity, and attention to the history of racial trauma, collaborations were stalled.

We also affirm the expectations set by scholars and practitioners for campus-community partnerships. We worked with community organizations to establish project goals and drew on their input to shape our curricular approach. Niewolny et al. (2017) also propose including student participation in course design and implementation, which could be a goal for our future practice. The concept of transformative learning from Clayton et al. (2010) also sets a high standard for relationships, including dimensions of outcomes, decision-making, common goals, resources, power, and satisfaction. In subsequent work, we could more formally assess community-campus relationships using Clayton et al.'s (2010) Transformational Relationship Evaluation Scale. Future food justice efforts can make relationships more transformative by focusing on the many dimensions of the community-campus relationship as outlined in Clayton et al. (2010). Although we communicated regularly with community partners to ensure thoughtful responses to their needs, in the future we will gather data to assess the costs and challenges as well as the benefits of our collaboration.

O ur challenges primarily involved the institutionalized privilege of academic institutions and of serving both students and community organizations, similar to those identified by Gray et al. (2012), Bortolin (2011), and Porter and Weschler (2018). We found it challenging to forge new interactions and establish clear communication in the context of deeply ingrained academic supremacy, racism, and other oppressive power dynamics. Future projects in similar contexts might consider articulating and addressing inequalities explicitly early on so that stakeholders can work together through these traumas. In future initiatives, we recommend agreeing upon functional communication channels, acknowledging that these may be culturally or locally specific. As well, collaborations with a wide variety of organizations might distribute resources more broadly.

Pedagogy in Servic L earning

We implemented many of the best practices in the literatures on community-campus engagement, service-learning, and food justice to develop our curricular approach. O ur curricular assumptions and experience coincide with the three-phased model for course design of Howe et al. (2014). While theirs was proposed for service-learning in general, ours applied developmental theories of learning to food justice.

Like G ray et al. (2012), we prioritized student preparation before intensive interaction with community organizations. We accomplished such preparation through the onion model of community-campus engagement and our cultural competency modules, which were planned and delivered by community partners. In contrast to the model of Howe et al. (2014), however, we incorporated more direct contact with community leaders at earlier phases of learning. $\mathrm{O}$ ur data suggest that at introductory levels, student learning included shifts in behavioral intentions regarding food consumption, such as the intent to buy local and organic foods and to value ethically produced foods. At intermediate levels, students learned to define food dignity and to describe structural aspects of the food system. They learned to notice separations between community and campus, value connections with community members, and identify their own abilities and roles for contributing to community change. At higher levels, students took fuller responsibility for projects requiring long-term commitment and involvement with community organizations. They were able to create and evaluate contributions to the organizations. Some demonstrated that they had internalized values of food dignity.

\section{Recommendations for 0 thers Considening Community-Campus Collaborations for Food Dignity}

We conclude with the following recommendations 
for academic stakeholders considering communitycampus collaborations for food dignity.

Recommendations for institutional change:

- Seek institutional support for civic engagement early in the process.

- Develop a formal institutional strategic plan for engagement and insert engagement goals into other strategic plans.

- Include training for faculty and students for civic engagement.

- D evelop awareness of academic supremacy and strategies for addressing it.

- Include acknowledgment of communitycampus collaborations in tenure and promotion criteria.

- Create administrative structures that facilitate efforts by faculty to build collaborations with communities.

- Cover administrative costs, compensate community partners, and offer faculty release time or financial compensation in collaborations.

Recommendations for building community-campus partnerships and requisite academic professional development:

- Build respectful relationships via active listening.

- Build relationships among multiple faculty and multiple organizations.

- Strive for an equitable partnership model and actively avoid a charity model.

- Address racial and class privilege and academic supremacy.

- Recognize that food justice deals with people's resources for survival.

- Move from transactional to transformative relationships.

Recommendations for pedagogy:

- Scaffold teaching and preparation for service-learning developmentally, offering increasingly deeper forms of involvement and responsibility.

- Emphasize humility and accountability.

- Create intentionally tiered forms of involvement, from class-based projects to engagement spanning multiple semesters and years. O ffer higher level options in addition to internships.

- Connect students across disciplines to address complex challenges of the food system.

\section{Acknowledgments}

We acknowledge our community partners for their hard work and patience, our students who inspire us, and the members of the FD project for the opportunity to explore these issues in a unique community-based project. We are also grateful to Christine Porter and Tim Shenk for feedback on several versions of this paper.

\section{References}

Alkon, A. H., \& Norgaard, K. M. (2009). Breaking the food chains: An investigation of food justice activism. Sociological Inquiry, 79(3), 289-305. https:// doi.org/ 10.1111/ j.1475-682X.2009.00291.x

Allen, P. (2008). Mining for justice in the food system: Perceptions, practices, and possibilities. A griculture and $\mathrm{H}$ uman V alues, 25(2), 157-161. https:/ / doi.org/ 10.1007/ s10460-008-9120-6

Anderson, L. W., \& Krathwohl, D. R. (Eds.) (2001). A taxonomy for learning, teaching, and assessing: A revision of Bloom's taxonomy of educational objectives. Boston, Mass.: Allyn \& Bacon (Pearson Education Group).

Bloom, B. S. (Ed.). (1956). Tax onomy of educational objectives. V ol. 1: Cognitive domain. New York: McKay.

Bortolin, K. (2011). Serving ourselves: How the discourse on community engagement privileges the university over the community. Michigan Journal of Community Service L earning, 18(1), 49-58. http:/ / hdl.handle.net/ 10613/ 4875

Bowles, S., \& Gintis, H. (2002). Schooling in capitalist America revisited. Sociology of E ducation, 75(1), 1-18. https:/ / doi.org/ 10.2307/ 3090251

Bringle, R. G., \& Hatcher, J. A. (2002). Campus-community partnerships: The terms of engagement. Journal of Social Issues, 58(3), 503-516. https:/ / doi.org/ 10.1111/ 1540-4560.00273 
Journal of Agriculture, Food Systems, and Community D evelopment

Broad, G. (2016). M ore than just food: F ood justice and ommunity change. O akland: University of California Press. https:// doi.org/ 10.1525/ california/ 9780520287440.001.0001

Buckley, D . D . (2016). The conœpt of serviœ learning in practice: A vehide for university student development? (Unpublished master's thesis). University of Hertfordshire, UK. Retrieved from http:/ / uhra.herts.ac.uk/ handle/ 2299/ 17338

Burley, D., Coker, E., May, B., McCarty T., Dickerson, E., Milligan, B., Moses, D., Sanchez, S., \& Hortman, R. (2016). Taking the challenge for real food: Student engagement in procuring sustainably produced food on campus. Journal of A griaulture, Food Systems, and Community D evelopment, 7(1), 71- 87. https:/ / doi.org/ 10.5304/ jafscd.2016.071.011

Burns, H., \& Miller, W. (2012). The Learning G ardens Laboratory: Teaching sustainability and developing sustainable food systems through unique partnerships. Journal of A griculture, Food Systems, and C ommunity D evelopment, 2(3), 69-78. http:/ / dx.doi.org/ 10.5304/ jafscd.2012.023.003

Cadieux, K. V., \& Slocum, R. (2015). What does it mean to do food justice? Journal of Political E cology, 22, 1-26. https:// doi.org/ 10.2458/ v22i1.21076

Clayton, P. H., Bringle, R. G ., Senor, B., Huq, J., \& Morrison, M. (2010). Differentiating and assessing relationships in service-learning and civic engagement: Exploitative, transactional, or transformational. Michigan Journal of Community Serviœ L earning, 16(2), 5-22. http:/ / hdl.handle.net/ 2027/ spo.3239521.0016.201

Clark, S., Byker, C., Niewolny, K., \& Helms, J. (2013). Framing an undergraduate minor through the civic agriculture and food systems curriculum. N A CTA Journal, 57(2), 56-67. Retrieved from https:/ / www.nactateachers.org/ index.php/ volume-57-num-2-june-2013/ 2070-framing-an-undergraduate-minorthrough-the-civic-agriculture-and-food-systems-curriculum

Cofer, J. (2017, A ugust 22). So you want to work at a teaching college? [Blog post]. Retrieved from The Chronicle of Higher Education website: https:/ / www.chronicle.com/ article/ So-You-Want-to-Work-at-a/ 240975

Enos, S. \& Morton, K. (2003). D eveloping a theory and practice of campus-community partnerships. In B. Jacoby \& Associates (Eds.), Building partnerships for serviœlearning (pp. 20-41). San Francisco: John Wiley \& Sons.

Eyler, J., \& G iles Jr., D . E. (1999). W here's the learning in servicelearning? San Francisco: Jossey-Bass.

Freire, P. (1970). Pedagogy of the oppressed. New York: Continuum.

Furco, A. (2002). Self-assessment rubric for the institutionalization of serviœlearning in higher education. Berkeley: University of California.

Furco, A. (2007). Institutionalising service-learning in higher education. In L. McIlrath \& I. M. Labhrainn (Eds.), H igher education and civic engagement: International perspectives (pp. 65-82). New Y ork: A shgate.

Galt, R. E., Parr, D ., Van Soelen Kim, J., Beckett, J., Lickter, M., \& Ballard, H. (2013). Transformative food systems education in a land-grant college of agriculture: The importance of learner-centered inquiries. A grialture and $\mathrm{H}$ uman V alues, 30(1), 129-142. https:// doi.org/ 10.1007/ s10460-012-9384-8

Gelmon, S. B., Holland, B. A., Seifer, S. D ., Shinnamon, A., \& Connors, K. (1998). Community-university partnerships for mutual learning. Michigan Journal of Community Service L earning, 5(1), 97-107. http:/ / hdl.handle.net/ 2027/ spo.3239521.0005.110

Gottlieb, R., \& Joshi, A. (2010). Food justiœe. Cambridge, MA: MIT Press.

Gray, L., Johnson, J., Latham, N., Tang, M., \& Thomas, A. (2012). Critical reflections on experiential learning for food justice. Journal of A griaulture, F ood Systems, and Community D evelopment, 2(3), 137-147. http:/ / dx.doi.org/ 10.5304/ jafscd.2012.023.014

Holland, B. A. (2016). Factors and strategies that influence faculty involvement in public service. Journal of $\mathrm{H}$ igher E ducation 0 utreach and E ngagement, 20(1), 63-71.

Holt-Giménez, E. (2010). Food security, food justice, or food sovereignty? F ood First Badk grounder, 16(4). Retrieved from https:/ foodfirst.org/ publication/ food-security-food-justice-or-food-sovereignty/

Howe, C. W., Coleman, K., Hamshaw, K., \& Westdijk, K. (2014). Student development and service-learning: A threephased model for course design. International Journal of Research on Service L earning and C ommunity E ngagement, 2(1), 4462. Retrieved from https:// journals.sfu.ca/ iarslce/ 
Hullender, R., Hinck S., Wood-Nartker, J., Burton, T., \& Bowlby, S. (2015). Evidences of transformative learning in service-learning reflections. Journal of the Scholarship of Teaching and L earning, 15(4), 58-82. https:// scholarworks.iu.edu/ journals/ index.php/ josotl/

Jacoby, B., \& Associates. (2009). Civic engagement in higher education: C oncepts and practices. San Francisco: Jossey-Bass.

Kiely, R. (2005). A transformative learning model for service-learning: A longitudinal case study. Michigan Journal of Community Service L earning, 12(1), 5-22. http:/ / hdl.handle.net/ 2027/ spo.3239521.0012.101

Kiely, R. (2007). Service learning as reflective practice: A four-lens model. In P. Horrigan (Ed.), E xtending our reach: V oices of service learning (pp. 64-70). Ithaca, NY: Comell University Press.

Kiely, R. and Sexsmith, K. (2018). Innovative considerations in faculty development and S-LCE: New perspectives for the future. In B. Berkey, C. Meixner, P. M. G reen, \& E. A. Eddins (Eds.), Reconœeptualizing faculty development in service learning/ community engagement: E x ploring intersections, frameworks, and models of practice (pp. 283-314). Sterling, Virginia: Stylus Publishing.

Levkoe, C. Z. (2006). Learning democracy through food justice movements. A griaulture and H uman V alues, 23(1), 89-98. https:// doi.org/ 10.1007/ s10460-005-5871-5

Levkoe, C. Z., McClintock, N., Minkoff-Zern, L. A., Coplen, A. K., Gaddis, J., Lo, J., F. Tendick-Matesanz \& Weiler, A. M. (2016). Forging links between food chain labor activists and academics. Journal of A griculture, F ood Systems, and Community D evelopment, 6(2), 129-142. https:/ / doi.org/ 10.5304/ jafscd.2016.062.009

Marullo, S., \& Edwards, B. (2000). From charity to justice: The potential of university-community collaboration for social change. A merican Behavioral Scientist, 43(5), 895-912. https:// doi.org/ 10.1177/ 00027640021955540

Meek, D., \& Tarlau, R. (2015). Critical food systems education and the question of race. Journal of A griaulture, Food Systems, and Community D evelopment, 5(4), 131-135. http:/ / dx.doi.org/ 10.5304/ jafscd.2015.054.021

Mitchell, T. D . (2008). Traditional vs. critical service-learning: Engaging the literature to differentiate two models. M ichigan Journal of C ommunity Serviœ L earning, 14(2), 50-65. http:/ / hdl.handle.net/ 2027/ spo.3239521.0014.205

Nemtchinova, K. (2013). Teaching-focused university. In R. Kubota \& Y. Sun (Eds.), D emystifying Career Paths after $G$ raduate School: A G uide for Second L anguage Professionals in H igher E ducation (pp. 35-47). Charlotte, N.C.: Information Age Publishing.

Niewolny, K. L., Grossman, J. M., Byker, C. J., Helms, J. L., Clark, S. F., Cotton, J. A., \& Jacobsen, K. L. (2012). Sustainable agriculture education and civic engagement: The significance of community-university partnerships in the new agricultural paradigm. Journal of A grialture, F ood Systems, and C ommunity D evelopment, 2(3), 27-42. https:// doi.org/ 10.5304/ jafscd.2012.023.005

Niewolny, K., Schroeder-Moreno, M. S., Mason, G., McWhirt, A., \& Clark, S. (2017). Participatory praxis for community food security education. Journal of A griculture, Food Systems, and C ommunity D evelopment, 7(4), 105-128. https:/ / doi.org/ 10.5304/ jafscd.2017.074.009

Phelps, H. (2013, September 13). D oing research at a teaching-focused college [Blog post]. Retrieved from the Inside Higher Ed website: https:/ / www.insidehighered.com/ advice/ 2013/ 09/ 13/ how-do-good-research-teachingintensive-institution-essay

Poppendieck, J. (1999). Sweet charity? E mergency food and the end of entitlement. New Y ork: Penguin.

Porter, C. M. (2018). G rowing our own: Characterizing food production strategies with five U.S. community-based food justice organizations. Journal of A griculture, F ood Systems, and C ommunity D evelopment, 8(Suppl. 1), 167-185. https:// doi.org/ 10.5304/ jafscd.2018.08A.001

Porter, C. M. \& Wechsler, A. (2018). Follow the money: Resource allocation and academic supremacy among community and university partners in Food Dignity. Journal of A grialture, F ood Systems, and Community D evelopment, 8(Suppl. 1), 63-82. https:/ / doi.org/ 10.5304/ jafscd.2018.08A.006

Rosing, H. (2012). Demystifying the local: Considerations for higher education engagement with community food systems. Journal of A griaulture, F ood Systems, and C ommunity D evelopment, 2(4), 79-84.

http:/ / dx.doi.org/ 10.5304/ jafscd.2012.024.005 
Sbicca, J. (2012). G rowing food justice by planting an anti-oppression foundation: O pportunities and obstacles for a budding social movement. A griculture and $\mathrm{H}$ uman $\mathrm{V}$ alues, 29(4), 455-466. https:// doi.org/ 10.1007/ s10460-012-9363-0

Sbicca, J. (2015). Solidarity and sweat equity: For reciprocal food justice research. Journal of A griaulture, Food Systems, and Community D evelopment, 5(4), 63-67. http:// dx.doi.org/ 10.5304/ jafscd.2015.054.004

Stoecker, R., \& Tryon, E. A. (2009). Community organizations and service learning. In R. Stoecker \& E. A. Tryon (Eds.), The U nheard V oices: C ommunity 0 rganizations and Service L earning (1-18). Philadelphia: Temple University Press.

Swords, A. C., \& Kiely, R. (2010). Beyond pedagogy: Service learning as movement building in higher education. Journal of Community Practio, 18(2-3), 148-170. https:// doi.org/ 10.1080/ 10705422.2010.487253

Ward, K., \& Wolf-Wendel, L. (2000). Community-centered service learning: Moving from doing for to doing with. A merican Behavioral Scientist, 43(5), 767- 780. https:/ / doi.org/ 10.1177/ 00027640021955586

Winne, M. 2008. Closing the food gap: Resetting the table in the land of plenty. Boston, Mass.: Beacon Press.

Yarbrough, D . B., \& Wade, R. C. (2001). Using program theory to build and evaluate service-learning programs. In A. Furco \& S. H. Billig (Eds.), Servicelearning: The essenœ of the pedagogy (pp. 103-123). Greenwich, Conn.: Information Age. 